\title{
Primary bone lymphoma
}

\author{
C Pissarro C Azevedo ${ }^{1 *}$, P José AFF Tavares ${ }^{2}$, M Isabel P Portela ${ }^{1}$, A José LCP Santos ${ }^{2}$, J Manuel PS Casanova ${ }^{2}$ \\ From 16th International Charles Heidelberger Symposium on Cancer Research \\ Coimbra, Portugal. 26-28 September 2010
}

\section{Background}

Primary bone lymphoma (PBL) accounts for $3 \%$ of all primary bone malignancies [1] and represents $<2 \%$ of all lymphomas in adults [2].

\section{Material and Methods}

Retrospective review of 25 patients with PBL treated at a single institution between 1995 and 2010.

\section{Results}

14 patients were female. The median age was 63 years (30-90). 13 had localized disease. The tumor had an axial location in 20 patients (80\%). 6 patients presented with a pathologic fracture. The histological type was NonHodgkin Lymphoma B in all patients. There were 18 high grade lymphomas. According to the IPI, 8 cases (32\%) were classified as low risk, 11 cases $(44 \%)$ as intermediate risk and $6(24 \%)$ as high risk. All patients received chemotherapy. 17 patients were treated with radiotherapy to a total dose that varied from 15 to $50 \mathrm{~Gy}$. 7 patients underwent surgical treatment. The median follow-up was 12 months (1-121). Recurrence of the disease was seen in 3 patients. 9 patients had disease progression. With regard to the status of the patients: 8 patients are continuously disease free; 3 patients are alive with disease; 10 patients died of the disease; 2 patients died of other cause. The 10 -year overall survival rate was $45 \%$. The 5 -year survival rate was $85 \%$ for low-risk IPI vs $35 \%$ for intermediate-risk IPI vs $18 \%$ for high-risk IPI.

\section{Conclusions}

Combined modality treatment results in good survival rates in patients with low-risk and intermediate-risk PBL.

\footnotetext{
* Correspondence: cristina.azv@gmail.com

${ }^{1}$ Department of Medical Oncology, Portuguese Oncology Institute of

Coimbra, Coimbra, Portugal

Full list of author information is available at the end of the article
}

\section{Author details}

${ }^{1}$ Department of Medical Oncology, Portuguese Oncology Institute of

Coimbra, Coimbra, Portugal. ${ }^{2}$ Bone and Soft Tissue Tumor Unit, Coimbra

University Hospital, Coimbra, Portugal.

Published: 24 September 2010

\section{References}

1. Limb D, Dreghorn C, Murphy JK, Mannion R: Primary lymphoma of bone. Int Orthop 1994, 18:180-183.

2. Dubey P, Ha CS, Besa PC, Fuller L, Cabanillas F, Murray J, Hess MA, Cox JD: Localized primary malignant lymphoma of bone. Int J Radiat Oncol Biol Phys 1997, 37:1087-1093.

doi:10.1007/BF00192476

Cite this article as: Azevedo et al.: Primary bone lymphoma. BMC Proceedings 2010 4(Suppl 2):P8.
Submit your next manuscript to BioMed Central and take full advantage of:

- Convenient online submission

- Thorough peer review

- No space constraints or color figure charges

- Immediate publication on acceptance

- Inclusion in PubMed, CAS, Scopus and Google Scholar

- Research which is freely available for redistribution

Submit your manuscript at www.biomedcentral.com/submit
Ciomed Central 